\title{
Changes in the Institutional Context of the Ombudsman System in the Republic of Hungary in 2012
}

\author{
Máté Szabó \\ Faculty of Political Sciences, Eotvos Lorand University of Budapest, Budapest, Hungary. \\ Email: szabo.mate@ajbh.hu
}

Received June $8^{\text {th }}$, 2012; revised July $10^{\text {th }}, 2012$; accepted July $22^{\text {nd }}, 2012$

\begin{abstract}
After the landslide electoral victory of the Fidesz-KDNP in 2010, the new Hungarian government with a two-thirds majority in Parliament adopted a new Constitution which significantly modified the previous institutional structure. Written by the former Commissioner for Civil Rights (as the Ombudsman of general competence used to be called) who is now Commissioner for Fundamental Rights, this article describes, analyses and evaluates the changes which terminated the previous Ombudsman system consisting of four Commissioners and established an independent authority to uphold information rights on the one hand, and a unified Ombudsman structure with increased responsibilities and powers on the other hand.
\end{abstract}

Keywords: Hungary; Ombudsman; Transformation; Constitutional Law

\section{Introduction}

After the democratic transition in 1989 the former Communist states tried to use every institutional arrangement to secure and stabilize the culture of human rights within the new institutional framework. The Ombudsman institution, which was an invention of the Swedish constitutional development 200 years ago, was received with great interest by the new democracies of Central and Eastern Europe. It was established without exception in every former Communist state. We are going to focus on the Hungarian development of the recent years after the "electoral revolution" of 2010, resulting in a two-thirds majority for the Fidesz-KDNP party coalition and enabling the new government to adopt a new constitution and a series of cardinal Acts which required a qualified majority of two-thirds of Members of Parliament. The new constitution (called Fundamental Law) and the new Ombudsman Act, both adopted in 2011 by Parliament and effective as of 2012, established the new institutional arrangement of the Ombudsman institution in Hungary.

\section{The Original Institution as Set Up by Act LIX of 1993 on the Parliamentary Commissioner for Civil Rights [1]}

Anybody may apply to the Ombudsman if they deem that the proceedings of an authority or organ performing public services, a decision or measure taken in the course of these proceedings, or an omission to act by any authority or organ performing public services have caused them a constitutional rights-related injury, or that an imminent danger thereof exists.

The Act of 1993 states that anybody may apply to the Ombudsman, if they deem that the proceedings of an authority or organ performing public services, a decision or measure taken in the course of these proceedings, or an omission to act by an authority or organ performing public services have caused them a constitutional rightsrelated injury, or that an imminent danger thereof exists.

The main task of the Parliamentary Commissioner for Civil Rights is to inquire into any improprieties related to constitutional rights he/she has become aware of and to initiate general or particular measures for their redress. The Parliamentary Commissioner for Civil Rights is solely accountable to Parliament. As for the legal status of the Ombudsman, in the course of proceedings he/she has to be independent and may take measures exclusively on the basis of the Constitution and Acts of Parliament.

The Ombudsman is elected for a six-year term by a majority of two-thirds of the votes of the Members of Parliament at the proposal of the President of the Republic. The Ombudsman may be re-elected for a second term.

The Act on the Ombudsman Gives an Exhaustive List of Authorities the Activities of Which the Ombudsman May Inquire into. These are:

- Organs or organizations performing tasks of state administration (e.g. town clerks, the Construction Authority, guardianship authorities, customs and ex- 
cise authorities);

- Any other body acting as state administrative authority;

- The police, the armed forces and the security services;

- Local governments, minority self-governments, the office of the mayor;

- Notaries public;

- Court bailiffs;

- Bodies performing a public service (e.g. water, gas and electricity suppliers, social services and health care, educational institutions, parking companies, public service media);

Fundamental rights may be infringed in particular by the following:

- Unreasonably long proceedings,

- Discrimination,

- Provision of inaccurate or wrong information,

- Unfair treatment,

- Refusal to disseminate information on unreasonable grounds,

- Unlawful decision.

A very important aspect of the Commissioner's role is that a complaint may only be filed if the complainant has already exhausted the available administrative remedies - except for judicial review of administrative decisions, or where no legal remedies are ensured.

Cases where the Ombudsman cannot help:

- If the proceedings have begun before 23rd October 1989 ,

- If the final administrative decision was made more than 1 year ago,

- If legal proceedings are pending or a final court decision has been rendered, or

- If the complainant has started judicial proceedings.

- The Ombudsman cannot inquire into the activities of Parliament, the President of the Republic, the Constitutional Court, the State Audit Office or the public prosecutor's office (except for the investigation office of the public prosecutor).

The Ombudsman selects him/herself the course of action that is deemed to be most appropriate. Key measures are:

- To make a request for remedy to the supervisory authority of the authority that has infringed constitutional rights.

- To initiate a remedy request at top management level.

- To file an application with the Constitutional Court for the examination of the unconstitutionality of a rule of law.

- To initiate (at a public prosecutor's office) the lodging of a public prosecutor's protest.

- To propose that the Law Commission amend or repeal an existing rule of law or that a new rule of law be adopted.

- To submit the case to Parliament and request a parliamentary inquiry.

\section{Main Directions of the New Ombudsman System from 2011}

The institution of Ombudsman itself is like a "ship being rebuilt on water". With the making of the new Fundamental Law the Ombudsman system was radically remodelled in such a way I as had been advocating it for years as Ombudsman: one single institution for the protection of rights, with deputies responsible for the fields of the rights of national and ethnic minorities, and environment protection, respectively.

During the parliamentary debate of the Fundamental Law and of the Ombudsman Act in 2011 all four Ombudsmen had the opportunity to express their views. Although certain structural elements of the new regulation are in accordance with my original concept, but I would not take responsibility for the entire normative content of the bases and final form of the new regulation, since this regulation, like all rules of law, is based on a multitude of political and legal compromises that might actually impair the unity of the original concept.

The new Fundamental Law changed the structure and competences of certain institutions of our system based on the rule of law; among others it changed that of the Ombudsman, an institution of human rights protection with 15 years of history. Instead of the four Ombudsmen established upon the Swedish model, the new Fundamental Law opted for having just one single Ombudsman institution. One reason could be that this system has been chosen by the great majority of European countries, as it allows a unified and interrelated interpretation of human rights, transparency, effectiveness and the concentration of resources to the most relevant issues. In countries having more than one Ombudsman (like Sweden, Austria, Lithuania, Moldova) one of them holds, permanently or on a rotational basis, the office of head of the institution. Such coordination has been missing until now in Hungary.

The Fundamental Law ("The State", paragraphs 1 to 5 of Article 30) stipulates two specialised deputies within the single Ombudsman system (both were separate Ombudsmen until the end of 2011). They have now taken over the functions of the former Commissioners for National and Ethnic Minority Rights and for Future Generations. The latter was established by the amendment of the relevant Act in 2007 and started operating in 2008. The designation "Commissioner for Future Generations" is misleading, as many countries in Europe and throughout the world operate a separate Ombudsman for protecting the rights of children, and the general meaning of "future 
generations” refers primarily to this function. In Hungary, however, protection of the rights of children has always been the competence of the general Ombudsman and the "rights of future generations" has meant in reality the institution protecting the rights laid down in the Act on Environment Protection. Consequently, the Commissioner for Future Generations was the "green" Ombudsman. Therefore, the previously autonomous Ombudsmen operated last year on the basis of the Minorities Act and the Environment Protection Act, as the specialised Deputy Commissioners do as of 1 January 2012. Their competence and procedures, just like the general Ombudsman's, are laid down in the Ombudsman Act (Act CXI of 2011 on the Commissioner for Fundamental Rights) [2] ${ }^{1}$.

In accordance with the Fundamental Law, a single Ombudsman institution has been established, in which the Ombudsman and his or her two specialised deputies are elected for a term of six years by a two-thirds majority of the Members of Parliament. The institution has been renamed; the designation "Parliamentary Commissioner for Citizens' Rights" has been replaced by "Commissioner for Fundamental Rights". More emphasis is laid on its task to turn to the Constitutional Court for $e x$ post review of norms, as the possibility of actio popularis ceased to exist; citizens and their organisations can turn to the Constitutional Court only via the Government, one-fourth of the Members of Parliament or the Ombudsman (paragraph (2)e) of Article 24).

Similarly to other institutions of public law and fundamental rights, the new Fundamental Law has not divested the institution of Ombudsman of its original character but left it unchanged; the Ombudsman is still an independent institution which aims to uncover improprieties endangering the enforcement of fundamental rights and makes recommendations to the Government, public administration or Parliament for redress. The institution, which is now undergoing unification, is expected to become more effective, to have a clearer policy and to enforce fundamental rights in their context; also, according to the decision of the makers of the Fundamental Law, the institution will pay special attention to the rights and interests of nationalities and of environment protection, which are now represented by the specialised deputies. At present the Ombudsman's control does not cover the activities of the courts and of the prosecution service (with the exception of the investigation organs of the Prosecution Service); neither can he or she conduct inquiries into private law entities unless their operation gravely infringes the fundamental rights of many citizens.

Where do I see further possibilities for improving the protection of fundamental rights in our more and more unified institution? In order to support the activity of the

${ }^{1}$ [2] Act CXI of 2011 on the Commissioner for Fundamental Rights.
High Commissioner for Human Rights in Geneva, the United Nations started to build a network of National Human Rights Institutions in the 90's that has became a global network by now. Previously there had not been such an institution in Hungary; therefore, in 2010 we submitted an application of accreditation to the coordinating office of the UN Human Rights High Commissioner. The application was decided favourably upon in 2011.

National human rights institutions operate in various structures, and in Europe this task is often performed by the Ombudsman. The activities of the institution are varied but it mainly contributes to the enforcement of the Universal Declaration of Human Rights and of the great international treaty systems (rights of children, women, refugees, persons with disabilities etc.) with the regular monitoring of implementation, with uncovering the obstacles and with recommendations to international organisations, governmental organs and parliaments. These UN accredited institutions cooperate with civil society's rights protecting organisations. They take part in human rights education and the gathering, classification and processing of information on human rights. Now this function is performed in Hungary by the unified Ombudsman institution. This may provide an opportunity for playing an intermediary role between governmental and non-governmental organisations (NGOs) in order to establish and develop our human rights culture. Hungary has a lot to do in order to implement UN conventions; this task often comes second after current domestic and foreign policy expectations and the enforcement of the interests of various government departments.

\subsection{Reasons for Remodelling the Hungarian Ombudsman System}

Why was it necessary to remodel the Ombudsman system in Hungary in 2011? Previously different Commissioners were established at different times, out of different legislative intentions, and their cooperation was not satisfactory. In Hungary it was unclear in how many and what cases people turned to the different Ombudsmen and to other authorities accepting complaints. Even though the four Ombudsmen had a common Office, there was no uniform procedure for or classification of complaints, not to speak of the ones submitted to the Equal Treatment Authority, to the Independent Police Complaints Board or to the fora of public media. Until now it has not been possible to form a comprehensive picture of the state of human rights in Hungary from the annual or long-term reports of several authorities or civil society organisations, as the precondition of such a report is the interconnection and systematic processing of databases. In the absence of such information tendencies of devel- 
opment cannot be seen, not even by those decisionmakers who are committed to make changes. Consequently, in the process of making the new constitution the legislator could not build on such comprehensive surveys.

Without proper information and sources that are available to everybody, the evaluations were one-sided and biased. Now a balanced and regular flow of information between different authorities may increase the effectiveness and precision of legislation and decision-making.

Another problem was that the great global and European international treaty systems of the last twenty years (e.g. on the rights of children, persons with disabilities or women) do not yet have independent control organs in Hungary that would monitor the implementation of these international standards in our country. This would require money from the central budget and the support of new civil society organisations having the right to access and control. Government organs in Hungary were unwilling to establish such independent control organs, although the country had committed itself in these treaties to do so. Also, our accession to the Optional Protocol to the UN Convention on the Prevention of Torture and Other Cruel, Inhuman or Degrading Treatment or Punishment (OPCAT) had been delayed for a long time. Accession would commit Hungary to operate a national monitoring authority within this optional international system; said delay was already criticised in the report of the parliamentary subcommittee which investigated the human rights violations of 2006. In 2011, the decision was made to accede to the OPCAT system and it was also decided that the main institution operating the control mechanism in Hungary would be the Commissioner for Fundamental Rights.

According to the Fundamental Law [3] $]^{2}$, the previous Commissioner for Data Protection ceases to operate as a separate Ombudsman from 1 January this year; his or her tasks are to be performed by an independent authority established by a cardinal Act ("Freedom and responsibility”, Article VI, paragraph 3). The previous Hungarian system was exceptional in Europe: the protection of data and freedom of information were not performed together within one institution in every country, and that institution was not in every case elected by and accountable to Parliament; on the other hand it had to be independent in accordance with EU law. Until 31 December 2011, however, due to their common Office, the Commissioner for Data Protection was tied to the other Ombudsmen dealing with completely different subject-matters. According to the new Act, the data protection authority is given certain public powers, like registration or even the power to impose heavy fines. Such powers, however, are hardly compatible with the competence of European-type

${ }^{2}[3]$ The Fundamental Law of Hungary.
Ombudsmen, which competence is restricted to making recommendations. Therefore, the cardinal Act had to establish a new authority for the exercise of these new public powers. The regulation pertaining to the new authority called National Authority for Data Protection and Freedom of Information, operating as of 1 January 2012, is under reconsideration as a consequence of European criticisms.

As laid down in the provisions effective as of 1 January 2012, the transitional provisions designate the former Commissioner for Civil Rights, to fill the office of the Commissioner for Fundamental Rights in the new, unified institution. I find it my duty therefore to do my best in this new system, to the establishment of which I have also contributed to some extent. I will endeavour to promote the successful development of the institution in cooperation with the other (also remodelled) constitutional institutions and with the specialised Deputy Commissioners. I presume the remaining almost two years might be enough to form the new institution's practices and to make suggestions to the law-maker for the correction of practical problems. Legislative changes have affected almost every part of our legal system, and they were also adopted according to a relatively hurried schedule, so it should not surprise us that this body of legislation is going to produce a series of problems that stem from internal incoherencies and which could only be partly overcome in practice. Consequently the regulations introduced as of 1 January 2012 need continuous corrections.

\subsection{Unaltered Role of Protecting Fundamental Rights}

The effective Ombudsman-type protection of rights has proved to be one of the basic cornerstones of guaranteeing fundamental rights since the first Ombudsman entered office in the summer of 1995. In accordance with the Fundamental Law, Parliament adopted an Act on 11 July 2011 on the unified Ombudsman system in order to create an effective, coherent and full protection of fundamental rights. Based on previous provisions of the Constitution, Article 30 of the Fundamental Law clarifies that the Commissioner for Fundamental Rights performs a general fundamental rights protection task, and that anyone can initiate proceedings with the Commissioner. As in the previous period, the Commissioner's primary task is in accordance with the classic role of Ombudsman: he or she inquires into the improprieties relating to fundamental rights or has these improprieties inquired into, and initiates general or specific measures for redress.

During the process leading to the adoption of Act CXI of 2011 on the Commissioner for Fundamental Rights (Ombudsman Act) the legislator considered several as- 
pects: first the practice of the last 15 years, secondly the experience of the application of the previous Ombudsman Act, thirdly the processes of the Ombudsman-type protection of rights, and finally examples of success in other European countries. Due to the advantages of a unified system, to the new features of the regulation and to the differentiated procedural rules, the new Ombudsman Act (applicable as of 1 January 2012) may increase the level of protection of fundamental rights. Furthermore, it is essential for the Commissioner to continue to cooperate with all parties of fundamental rights protection: with the Constitutional Court, with the courts and with civil society organisations for the protection of rights.

Concerning information rights, it brings new possibilities that the tasks and competences of the Commissioner for Data Protection (including authority-type public powers) have been taken over by an independent authority. In the single Ombudsman model specialised Deputy Commissioners are responsible for the special protection of the interests of future generations and the rights of nationalities living in Hungary, respectively. Deputy Commissioners have various tasks; their activities are based on internal professional cooperation and coordination. They monitor the enforcement of the fundamental rights concerned, regularly inform the Commissioner on their relevant experience, call his or her attention to the danger of violation of rights of larger groups of natural persons, may propose the starting of ex officio proceedings, contribute to the inquiry of the Commissioner for Fundamental Rights, and finally they may propose that the Commissioner turn to the Constitutional Court.

In the future too, the Ombudsman's activities will, among others, focus on the protection of the rights of individuals who are not, or not entirely capable of enforcing their rights. In the course of their work, Parliamentary Commissioners paid special attention to the situation of persons living with disabilities. The Ombudsman Act gives a legal expression to this already existing role and attitude, stipulating that the Commissioner for Fundamental Rights, in the course of his or her activities, has to pay special attention to assisting, protecting and supervising the implementation of the UN Convention on the Rights of Persons with Disabilities, especially by conducting ex officio proceedings. The situation is much the same regarding the protection and enforcement of the rights of children, where the Ombudsman has been trying to achieve results with all legal and other tools at his disposal since 2007 by launching special projects and promoting legal awareness. Furthermore, the Ombudsman Act designates other social groups to the rights of which the Commissioner for Fundamental Rights has to pay special attention, following the rights protection philosophy of previous Ombudsmen.
The list of redefined and new tasks does not end here. Up until now, there have been no uniform statistical data on violations of fundamental rights. For the first time, the Ombudsman Act stipulates that the Commissioner for Fundamental Rights shall keep statistics on the violation of fundamental rights; other organs of fundamental rights protection (like the Equal Treatment Authority, the National Authority for Data Protection and Freedom of Information and the Independent Police Complaints Board) are obliged to supply data as well. This will allow us to have a comprehensive and true picture of the situation of human rights and the tendencies of committed infringements in any given year.

Compared to the former regulation, the competences of the Commissioner for Fundamental Rights have expanded, in exceptional cases he now has the right to inquire into the activity or omission of organisations other than authorities as well, if their activity or omission gravely infringes the fundamental rights of a larger group of natural persons. In such exceptional cases the Commissioner may initiate proceedings with the competent supervisory authority as a result of the inquiry. Consequently, the Ombudsman Act enables the Commissioner to act in order to protect the right to a healthy environment when this right is violated by other organisations than authorities or by public utility providers.

The scope and nature of the classic tools and methods of inquiry and the applicable measures have not changed significantly. However, the Act has become more distinct in this aspect than the previous one. The detailed regulations and definitions (for instance those of authority, impropriety, and ex officio inquiries) are in accordance with the former practice of the Ombudsman and they help a flexible and effective interpretation of the Ombudsman's tasks and competences. The regulation in the Act concerning the competence of initiating the adoption or amendment of rules of law is also progressive. It ensures that the Commissioner for Fundamental Rights may propose to the law-maker the revision of a legal regulation if improprieties are established in individual cases, unless the impropriety only occurred due to the proceedings of the authority or public utility provider. The possibility of taking parallel measures greatly helps to provide a complex solution for uncovered legal problems.

In order to redress improprieties, the Ombudsman Act increases the effectiveness of the protection of rights by ensuring the possibility of new, even immediate measures. For instance, the Prosecution Service is to be informed when the Commissioner's inquiry draws the conclusion that a coercive measure has been ordered unlawfully. The possibility that the Commissioner may now refer a petition to the prosecutor if he or she established no impropriety but becomes aware of circumstances pointing to the infringement of a rule of law also contributes to the 
redress of injuries. Based upon the Ombudsman Act and the previous experience, the Ombudsman issued a normative instruction on the professional rules and methods of inquiries. The Commissioners have always considered the rulings of the Constitutional Court authoritative on the content of fundamental rights. After the entry into force of the Fundamental Law the Commissioner for Fundamental Rights intends to continue this practice. As a consequence of the constitutional changes, the institution of actio popularis, which made it possible for everybody to turn to the Constitutional Court, was terminated on 1 January 2012. The Commissioner for Fundamental Rights is still entitled, besides the Government or one-fourth of the Members of Parliament, to initiate an examination of rules of law with the Constitutional Court for their compliance with the Fundamental Law or for determining whether they are in conflict with international treaties. Furthermore, according to the new Ombudsman Act and the Act on the Constitutional Court, the Ombudsman's inquiry or report are not preconditions of an application to the Constitutional Court. Filing an application for the ex post review of norms may not only be made as a measure: the Ombudsman may exercise this competence of his or hers upon anyone's complaint or $e x$ officio, stating his reasons and requesting that the Constitutional Court examine the issue. Doing so, he or she takes on the role of a mediator, and may become a fast, flexible and active initiator of detecting and removing from the legal system those Acts and rules of law which violate the Fundamental Law or international treaties on human rights.

According to the new regulation the Commissioner for Fundamental Rights can also act as a bridge or mediator between the national and international rights protection mechanisms in numerous important fields of fundamental rights. Only the formal framework seems to be a novelty, as Commissioners have always applied and invoked international and European human rights standards, requirements and commitments undertaken by Hungary. The new Act stipulates further tasks; it clarifies that, upon appointment, the Commissioner for Fundamental Rights performs the tasks of national mechanisms in accordance with Hungary's commitments undertaken in international treaties. Serious preparations need to be made, since the national preventive mechanism laid down in the Optional Protocol of the UN Convention against Torture and Other Cruel, Inhuman and Degrading Treatment or Punishment (OPCAT) will be performed by the Commissioner for Fundamental Rights as of 2015. There is no doubt a solid basis to build on; the protection of the rights of detainees and the conducting of inquiries into the functioning of and conditions in penitentiary institutions has always been attributed special importance in the Ombudsman's practice so far.
The new regulation, laid down in an Act of Parliament, allows the Commissioner for Fundamental Rights to become not only an esteemed member of the mechanism for the protection of fundamental rights in Hungary but also a responsible, central and active player who can shape the practice of fundamental rights, and whose activity is based on cooperation and the persuasive power of publicity and of constitutional arguments. The Ombudsman Act confirms the Ombudsman's philosophy, according to which-beyond the classical tasks of Ombudsmen (i.e. those of conducting inquiries and issuing recommendations in concrete cases) - the promotion of preventive and proactive protection of rights, of legal awareness and of communication between the parties are also indispensable for the enforcement of constitutionality in everyday social relations.

Changes are neither "good" nor "bad" in themselves. They should be justified by their results, about which I am optimistic. Not only the unification of the different Ombudsman's offices but also the very significant enlargement of the Ombudsman's competences open up wide perspectives of development instead of the dead-ends of the former fragmented system. However, results should be achieved in a "suboptimal" and crisis-ridden climate. Therefore, organisational effectiveness should be optimised in a suboptimal environment, which is not easy, but it is not impossible either.

We have been given quite a lot of means and tools to fulfil our mission. These are our new competences, the advantages of a unified management, the benefits of the integration of the formerly fragmented fields, the help of a civil society interested in working with us because of our competence to turn to the Constitutional Court, the possibility of exceptional inquiries into the fundamental rights related improprieties of private organisations, our widening competence in the institutional monitoring of the implementation of international treaties as national institutions of human rights, and mediation between domestic and international law.

\section{Relations between the Commissioner for Fundamental Rights and Other Constitutional Institutions Following the Entry into Force of the Fundamental Law}

\subsection{The Commissioner for Fundamental Rights and the Constitutional Court}

On the basis of the Fundamental Law the Constitutional Court continues to be a body for the performance of constitutional protection, since it is the principal organ for the protection of the Fundamental Law; its primary task is the review of norms, in other words the examination and annulment of rules of law which are contrary to the Fundamental Law. Moreover, in constitutional complaint 
proceedings citizens can now initiate the review not only of rules of law but also of concrete judicial decisions.

In the new constitutional system relations between the Hungarian Ombudsman, who performs a very important fundamental rights protection function, and the Constitutional Court may undergo significant changes and transformations. There is no change in that the Commissioner may not inquire into the activities or decisions of the Constitutional Court, and the decisions of the Constitutional Court are binding on the Commissioner for Fundamental Rights, as they are on all other organs. Tenets and tests set out in the decisions of the Constitutional Court on certain constitutional principles and fundamental rights continue to be authoritative for the Commissioner.

It is a significant change, however, that as of 1 January 2012 only certain persons and organs may turn to the Constitutional Court. Besides the Government or one fourth of all Members of Parliament, the Commissioner for Fundamental Rights may also initiate a review of the conformity of rules of law with the Fundamental Law if he or she considers that the rule of law is contrary to it. We find it necessary to mention this because the new regulation on the Constitutional Court does not ensure actio popularis any more, i.e. it does not allow that citizens without a legal interest initiate the review of the constitutionality of a rule of law.

On the basis of an inquiry conducted upon a concrete complaint and following the establishment of a situation infringing a fundamental right, the Ombudsman, as in the past, still has the possibility to file an application with the Constitutional Court in order to request the ex post (after adoption) review of the contested regulation. As a result of the narrowing of the right to file petitions there is a steady increase in the number of those complaints arriving to the Commissioner where the proceedings of the Ombudsman are not initiated in connection with particular cases involving an authority but complainants request him to turn to the Constitutional Court in connection with a rule of law. According to the Ombudsman Act the Commissioner also has the possibility to file petitions with the Constitutional Court directly on the basis of submitted complaints without conducting proceedings or inquiries. For filing direct petitions one should consider especially the gravity of the existing fundamental rights violation, the number of injured persons and the group(s) these persons belong to.

Moreover, the Commissioner also has the right to initiate a review of the constitutionality of rules of law which have already been adopted and published but not yet entered into force. Furthermore, if there is prima facie evidence that the rule of law is contrary to the Fundamental Law, the Ombudsman may request that the Constitutional Court temporarily suspend its entry into force. This may be done if it is necessary to take imme- diate measures to avoid serious and irreparable damage or disadvantage, or to protect the Fundamental Law or legal certainty.

The Act on the Constitutional Court $[4]^{3}$ gives the right to the Commissioner for Fundamental Rights to initiate-besides one fourth of all Members of Parliament, the Government, the President of the Curia and the Prosecutor General-that the Constitutional Court examine whether rules of law are in conflict with international treaties. Ombudsmen had the same right under the previous Ombudsman Act to initiate these special types of proceedings with the Constitutional Court, but the new circumstances we pointed out earlier, i.e. the narrowing of the circle of those who may submit petitions, may render the application of this instrument even more significant. The Commissioner for Fundamental Rights may initiate directly, on the basis of a petition submitted, that the Constitutional Court establish not only that a rule of law is contrary to the Fundamental Law, but also that it is contrary to an international treaty. Such relevant international treaties are for example the European Convention on Human Rights or the relevant case-law of the European Court of Human Rights interpreting the Convention. Other instruments belonging to this category are the Charter of Fundamental Rights of the European Union and several important human rights conventions, in particular the Convention on the Rights of the Child or the Convention on the Rights of Persons with Disabilities.

Another change is that in the new system the review of local government decrees is not done in principle by the Constitutional Court but by ordinary courts. If the complainant requests the Commissioner to initiate proceedings of the Constitutional Court in connection with a local government decree which is contrary to an Act, then -considering whether the decree is directly contrary to the Fundamental Law or not - the Ombudsman may start an $e x$ officio inquiry in the given case, and within its framework may ask the competent Government Office to conduct an inquiry. Pursuant to the Fundamental Law, if the Metropolitan or County Government Office finds that the local government decree or any of its provisions is contrary to a rule of law, it may apply to a court for a review of the local government decree. Thus, the Commissioner does not have the right to go to court directly in such cases.

We also have to point out that pursuant to the Act on the Constitutional Court neither the Commissioner, nor other organs or persons have the right and possibility any longer to initiate proceedings for the establishment of an unconstitutional situation which is manifested in a failure to act. The establishment of a failure by the law-maker to act is now exclusively in the competence of the Constitu-

${ }^{3}[4]$ Act CLI of 2011on the Constitutional Court. 
tional Court; it may do so ex officio, but external initiatives are excluded by the Act. In connection with the above it is also worth mentioning that on the basis of the Act on the Constitutional Court the Commissioner for Fundamental Rights, unlike under the previous regulation, may not request an abstract interpretation of the Fundamental Law: only Parliament or its committees, the President of the Republic, or the Government have the right to initiate such proceedings.

\subsection{The Commissioner for Fundamental Rights and the Courts}

In accordance with the classical institutional model of the Ombudsman, the Ombudsman Act does not allow the Commissioner for Fundamental Rights to inquire into the activities of the courts. The Act further stipulates that the Commissioner for Fundamental Rights may not proceed in cases where court proceedings have been started for a review of the decision or where a final court decision has been rendered. The regulation laid down in the Act is consistent: not even in exceptional proceedings does it allow the Commissioner to conduct inquiries into the activities of the courts, into the contents of judicial decisions or into procedural issues.

Consequently, like under the previous legislation, the Commissioner has no competence for inquiry in the case of complaints where the complainant contests the content of a judicial decision or the proceedings of the court, or if the complainant started judicial proceedings or judicial proceedings have been started by another party in the case.

It is important, however, to stress here that pursuant to the Ombudsman Act the Commissioner still has competence to examine in-merit the matters raised in complaints submitted against the activities of court bailiffs, in particular against county bailiffs and independent court bailiffs, within the limits of competence established in the practice so far. Here it has to be mentioned that the Commissioner may not act in matters explicitly referred to the competence of the courts by a rule of law, nor may he act in matters where the parties availed themselves of the legal remedies in court, such as the submission of an objection to execution.

In connection with submissions related to the courts the Commissioner has a very important role to provide information: in his or her letter refusing the starting of an inquiry he or she provides detailed information on the available legal remedies, and, where necessary, on the possibility of legal aid. In judicial proceedings the Commissioner may not represent the complainants.

If analysis of the submitted complaint shows that the conditions required for the submission of a constitutional complaint may be met, then in his or her response the Commissioner for Fundamental Rights, apart from rejecting the complaint for lack of competence, may inform the complainant about the conditions for submitting a constitutional complaint to the Constitutional Court on the matter at hand. At the same time it is essential to mention that in the constitutional complaint proceedings the Commissioner may not file the application or "represent" the complainant.

It might occur that the submitter of a petition objects exclusively to a rule of law (or its provision) concerning the procedure or functioning of the courts. In this event the Commissioner-since not a concrete, specific judicial decision is at issue-may consider whether he or she should request the Constitutional Court to examine the given regulation.

Finally, mention must be made of a peculiar legal institution, the letter of amicus curiae. In exceptional and justified cases it is possible for the Commissioner, considering the example of legal institutions well-known and utilised in international legal practice and legal literature (like the amicus curiae and Gutachten), to explain his position to the court on certain objective issues of legal interpretation not related to the case at hand or the decision made therein. In the practice of earlier Ombudsmen this has already been done in a few cases, and the new Ombudsman Act does not exclude this possibility either.

\subsection{The Commissioner for Fundamental Rights and the Prosecution Service}

As a consequence of the constitutional legal status of the Prosecution Service, our cooperation with that institution mainly consists of the handling of complaints related to proceedings of the police. Pursuant to the Ombudsman Act, investigating authorities, and in particular organs of the Prosecution Service that conduct investigations, belong to those organs the activities of which may be inquired into by the Commissioner.

Our Office receives numerous complaints in which complainants contest the legality of measures taken by the police in the framework of criminal proceedings. In many cases complainants turn to us because as suspects, accused persons or victims in criminal proceedings they are treated by the police in an inequitable manner, or in extreme cases they even suffer physical violence.

If there is a well-founded suspicion that a crime has been committed, the Commissioner is bound by the Ombudsman Act to report it to the competent authorities. The Commissioner, in the course of criminal proceedings initiated by him or her and up until charges are brought, may at any time use his or her right to inquire into the activities or omissions of the investigating authority. Consequently, if in connection with the investigation or the lack of it a fundamental rights infringement occurred or there is an imminent danger thereof, the Commissioner may request the starting of an investigation or the continuation thereof. At the initiative of the Commis- 
sioner, the Prosecution Service is bound to examine whether it is appropriate to quash the decision rejecting the denunciation or terminating the investigation.

There are intensive contacts and cooperation with the Prosecution Service in the course of those inquiries of the Ombudsman that concern the activities of penitentiary institutions and the enforcement of the rights of detainees, since the Prosecution Service exercises supervision over the legality of the operation of penitentiary institutions.

The Prosecution Service is a strategic partner of the Commissioner for Fundamental Rights in another respect as well. The Act on the Prosecution Service $[5]^{4}$ stresses that prosecutors are, within the framework of their obligation to protect the public interest, guardians of the legality of proceedings conducted by the authorities and other organs applying the law. In this role of theirs they may initiate or start contentious and non-contentious proceedings and other proceedings regulated in an Act, or participate in such proceedings. If an infringement or unlawful failure to act comes to the knowledge of the Prosecution Service, it supervises the legality of those final or enforceable decisions, official measures and proceedings of authorities and of other organs applying the law (with the exception of the courts) which have not been reviewed by a court. It exercises a supervision of legality over the proceedings, decisions and functioning of organs and organisations defined by an Act and contributes thereto that the administration of justice be accessible also to those persons who are not able to enforce their rights owing to their disabilities, age, situation or to any other reason. By reason of all these functions of the Prosecution Service it is of crucial importance that the Commissioner for Fundamental Rights co-operate therewith.

\section{Conclusions}

Since the elections in 2010, the Fidesz-KDNP government, having a two-thirds majority in Parliament, has made rapid and significant changes in almost all areas of the Hungarian legal system. The adoption of a new Constitution (the so-called Fundamental Law) and a new Ombudsman Act brought important modifications in the Ombudsman institution and in its place in the Hungarian constitutional system. We have to stress, however, that the continuity of the institution has not been essentially affected by these modifications, since its basic function of protecting fundamental rights has not changed, its independence and impartiality are still basic requirements, and the classical Ombudsman functions like receiving complaints, conducting inquiries, making recommendations, using the force of persuasion and publicity, and applying to the Constitutional Court have remained untouched.

${ }^{4}[5]$ Act CLXIII of 2011 on the Prosecution Service.
Nevertheless, important changes have been affected as well. First of all, instead of the former fragmented system of four Ombudsmen, now we have a unified Ombudsman system with more differentiated procedural rules and stronger powers. One new feature is the constitutional complaint, which-after the termination of the actio popularis - is the best way for individuals and civil society as a whole to raise the issue of constitutionality of rules of law through the intermediation of the Ombudsman, thereby partially setting the agenda of the Constitutional Court. A second new procedure is the exceptional inquiry, empowering the Ombudsman to conduct inquiries into the activities or omissions to act of private organisations if they gravely infringe the fundamental rights of a great number of natural persons. As of 2015 another new competence of the Ombudsman will be the performance of tasks related to the national preventive mechanism, to prevent torture and other cruel, inhuman or degrading treatment or punishment. Moreover, as a National Human Rights Institution the Ombudsman is also responsible for human rights education and the gathering, classification and processing of information on the human rights situation in the country.

As a result of the new Ombudsman regulation, there is a real opportunity for clearer, more coherent Ombudsman policy and practice, for a more unified interpretation of human rights, and for a concentration of resources on the most relevant issues. These all make the single Ombudsman more efficient and effective, and may increase the level of fundamental rights protection.

In fact, if the institution makes good use of the tools and instruments at its disposal, and in spite of the suboptimal environment characterised by the global crisis, it can become a fast, flexible and active initiator of detecting and removing from the legal system the rules of law that are contrary to the Fundamental Law or international treaties. Therefore, the Ombudsman institution can fulfil the function of a mediator within the Hungarian constitutional system as well as between the national and international rights protection mechanisms, and, by doing so, it can become an important actor in the system of checks and balances in Hungary.

\section{REFERENCES}

[1] "Act LIX of 1993 on the Parliamentary Commissioner for Civil Rights,” 1993. www.parlament.hu

[2] "Act CXI of 2011 on the Commissioner for Fundamental Rights,” 2011. www.parlament.hu

[3] “The Fundamental Law of Hungary,” 2012. www.mkab.hu/rules/fundamental-law

[4] “Act CLI of 2011 on the Constitutional Court," 2011. www.mkab.hu/rules/act-on-the-cc

[5] “Act CLXIII of 2011 on the Prosecution Service,” 2011. 